\title{
A Qualitative Study on the Perceptions of Administrators and Teachers on Procrastination Behavior and Workload of School Administrators
}

\author{
Melike Cömert ${ }^{1}$, Burhanettin Dönmez ${ }^{1}$ \\ ${ }^{1}$ Inonu University, Education Faculty, Department of Educational Administration, Malatya, Turkey \\ Correspondence: Melike Cömert, Inonu University, Education Faculty, Department of Educational Administration, \\ Malatya, Turkey.
}

Received: December 16, 2018

Accepted: December 27, 2018 Online Published: January 8, 2019

doi:10.11114/jets.v7i2.3881

URL: https://doi.org/10.11114/jets.v7i2.3881

\begin{abstract}
In the research, a total of 12 school administrators and 18 teachers working in six different schools including three primary schools and three secondary schools were interviewed by using "case study" of qualitative research techniques in order to get in-depth knowledge about school administrators and teachers' perceptions of postponement behaviors and workloads. When the managers and teachers to be interviewed were determined, the maximum diversity sampling method which is one of the purpose sampling methods was used. The qualitative data obtained in the research were collected by using semi-structured manager and teacher interview forms that prepared by the researcher. Within the scope of the research, in the context of the qualitative findings obtained from interviews with school administrators; all of the interviewed school administrators $(\mathrm{f}=12)$ stated that they did not postpone the work related to students, staff and education in the school, but they pointed out that sometimes there could be delayed situations. A large number of interviewed teachers $(f=13)$ indicated that the managers postpone many jobs in the school. In this context, internalization of managers, not only external sanctions, but also effective time management and internal supervision skills can be improved. In this context, internalization of managers, not just external sanctions, but effective time management and internal audit skills can be improved.
\end{abstract}

Keywords: school manager, teacher, postponement behaviors, workload

\section{Introduction}

The current times witness an era of incredible advances in technology and science. Technological and scientific advances facilitate social life on the one hand, while on the other lead to a complex organizational and social structure, and increasingly add to the workload of individuals. Thus, in order to cope with changes and survive, individuals and organizations should plan their tasks in advance, use time effectively, and establish a certain order of priority among their tasks (Güçlü, 2001).

Previous studies demonstrated that procrastination tendency or trend is a common problem in individuals in all walks of life (Çakıc1, 2003; Gülebağlan, 2003; Ferari, Johnson \& McCown, 1995; Senecal, Koestner \& Vallerand, 1995). For example, it was determined that $15-20 \%$ of adults participating in a study by Harriott and Ferrari (1996) constantly procrastinated. Certain research findings also demonstrated that procrastination behavior was frequent among university students and this behavior often led to negative academic results (Solomon \& Rothblum, 1984). In a study conducted by Uzun-Özer (2005), 52\% of the undergraduate students attending Middle East Technical University exhibited procrastination behavior in academic studies.

In their book "Procrastination and Task Avoidance: Theory, Research and Treatment," Ferrari, Johnson and McCown (1995) reported that procrastination existed throughout history, however the concept is entirely a modern phenomenon. The term procrastination is a combination of "pro" that means "forward" and "crastinus," which means belonging to tomorrow (Ferrari, Johnson and McCown, 1995). The word has also the meaning of avoiding acting without thinking during war (Subotnik et al, 1999). In this definition, delay is used to indicate that in some cases it is necessary and wiser to delay decision-making (Ferrari, Johnson \& McCown, 1995). With this definition, the concept has a positive meaning. However, after the industrial revolution; when planned work and punctuality became important, the concept achieved a different and negative meaning of idleness or laziness (Ferrari, Johnson and McCown, 1995; Subotnik et al, 1999).

Ellis and Knaus (1977, cited by Galue, 1990) defined procrastination as postponing or delaying a task. Johnson et al. 
(2000) defined procrastination as experiencing unnecessary delays due to incomplete work, completing work within a period longer than the planned time or on time but in an unsatisfactory manner.

Solomon and Rothblum (1984) described procrastination as the behavior of delaying a job, duty, or responsibility for no reason, which often leads to uncomfortable emotions. Milgram and Tenne (2000) described procrastination as a personality trait or behavioral tendency to delay work, avoiding tasks or decision making.

Based on the above-mentioned definitions, procrastination is consciously, unnecessarily or aimlessly delaying beginning, maintaining and completing a task, although the individual has the necessary resources, authority and skills to conduct a task, and making a habit of that behavior.

There are times in individuals' lives when they postponed their duties. However, all delaying behavior could not be considered as procrastination. There are certain criteria to characterize a behavior as procrastination. For example, according to Tuckman (1990), procrastination is a result of the combination of three conditions: one's disbelief about completing a task, one's inability to give up one's comfort, and one's reflection of one's own fault to external factors.

If a task cannot be completed or delayed due to lack of required authority and resources, it is not possible to consider that behavior as procrastination (Ferrari, 1994; Tuckman, 1991).

In addition to its adverse effects, procrastination also has positive effects. For example, it can sometimes help the individual to delay a task to have accurate insight or create the required motivation to achieve the ultimate goal. However, if the task has a deadline, procrastination becomes an important problem, since procrastination is a significant source of stress (Cunningham, 2007). Johnson, Green and Kluever, (2000) also reported that there was a correlation between procrastination trend and time of graduation, low grades and dropping out of school behavior.

\section{Area Descriptions}

\subsection{The Dimensions of Procrastination}

Studies in the literature demonstrated that procrastination is not just a behavioral problem related to time management. There is a consensus among researchers that procrastination is not generally behavioral such as avoiding or delaying tasks, but has cognitive and emotional dimensions (Ferrari, 1995; Milgram, 1991; Solomon \& Rothblum, 1984; Watson, 2001). Burka and Yuen (2008) reported that procrastination behavior might may differ between individuals, however procrastinators experience certain common emotions, thoughts and behavior. In this context, procrastination could be defined as a complex process with emotional, cognitive and behavioral dimensions.

The behavioral dimension of procrastination includes delaying behavior induced by the habit of continuous procrastination, the cognitive dimension includes the discrepant habit between the intentions, priorities and goals related to a task and their productivity when fulfilling this task, and the emotional dimension involves the stress that the individual feels due to the habit of not beginning a task, inability to work, or not completing the task before the deadline (Chu and Choi, 2005; Vestervelt, 2000; Çakıc1, 2003).

Although it is categorized as a negative personality trait, it was reported that procrastination may be beneficial in certain cases. For example, sometimes delay of a task by the individual could help the individual to make more accurate predictions, or to create the necessary motivation to achieve the ultimate goal (Cunningham, 2007).

The studies in the literature demonstrated that the roles and duties of school principals constantly change due to the changes and developments in social life (Dipaola \& Walter-Thomas, 2003; Hallinger, 1992; Portin, 2000; Williams \& Portin, 1997; Whitaker, 1998; 1999; 2002). For example, in the United States, the National Policy Committee on Education Administration, the National Directorate Commission and the Educational Leadership Institute developed new leadership programs to help administrators improve their capacity based on their changing roles (Whitaker, 2002). Certain researchers emphasized that the roles of the principals underwent an evolutionary process, and administrators should now exhibit the roles of an instructional and transformational leader rather than the traditional role of a principal (Hallinger, 1992).

In this context, school principals are responsible for several tasks such as human resources, monitoring the school budget, internship procedures, to control the school shuttles, to supervise the school canteens, to ensure the safety in the school and school environment, to ensure student discipline, to establish a relationship between the school and the community, to increase the technological opportunities in the school, enable active participation, etc. (Başaran, 2000; Groff, 2001; Taymaz, 2000) All the roles and responsibilities of school administrators about the management of the school constitute their workload.

The workload occurs when it required that an employee to complete several tasks with limited resources within a very limited time. Similarly, the workload of an employee is associated with factors such as reduced attention, prolonged response time, inability to fulfill the tasks, stress, fatigue and a decrease in performance (Uysal, Akbulut \& Ertan 2015). 
Workload can be defined as the individual's perception that the work assigned to him / her at the workplace is above normal or various pressures that affect the performance or reactions of the employee (Erdem, K1lınç \& Demirci, 2016).

The workload is described as the demand of work over the performance that the employees could perform in an organization and the excessive workload caused by insufficient number of staff, organizational downsizing and the increase in periodic demand are of great importance for work psychology. Thus, workload is a factor that needs to be identified and a correlation should be established between workload and work psychology and performance (Uysal et al, 2015).

The workload defines the intensity of the work that includes the work speed and the strength requirements (Bolat, 2011). In recent years, factors such as increased workload, working hours, and pace lead to several adverse effects on the employees such as the stress. Problems that aggravate the workload of employees should be identified and studies on prevention of these problems should be developed (Vatansever, 2014). Thus, procrastination would be prevented and the quality of work would be improved.

\section{Method}

The present study data were collected with qualitative research techniques. Since the present study is a qualitative research, a study group was created. The study group is commonly used in qualitative studies. These studies focus on how the factors related to a situation affect the situation and how they are affected by the situation in order to obtain in-depth information without generalization.

\subsection{The Study Group}

In the qualitative dimension of the study, interviews were conducted with administrators and teachers to obtain in-depth knowledge on the procrastination behavior exhibited by the school administrators and their workload.

During the interviews conducted on the procrastination behavior and workloads of the administrators, 12 school principals employed in three primary and three middle schools were interviewed. However, 18 teachers employed in the same schools were interviewed since it was considered that they would have more realistic views on the behavior and workloads of the administrators.

The administrators and teachers in the study group were determined with the qualitative method. This method was selected to include the views of the administrators and teachers with different gender, fields, seniority, and education levels in the study group and the objective was not to ensure diversity for generalization, but to determine whether there were common or shared phenomena between the different cases and to reveal the different dimensions of the problem based on the diversity (Yıldırım \& Şimşek, 2005).

\subsection{Data Collection Instruments}

The qualitative study data were collected with semi-structured interview forms developed by the author. Detailed information on the interview forms was included in the interview forms.

\subsubsection{Administrator and Teacher Interview Form}

In order to collect detailed information on the procrastination behavior of school principals, interviews were conducted with school administrators and teachers. Interview forms are developed to collect the same kind of information from different subjects on similar topics (Yıldırım \& Şimşek, 2005). Interviews with administrators and teachers were conducted with semi-structured administrator and teacher interview forms developed by the author. In the interviews, the voice recorders were used with the approval of the participants in order to conduct and record the interviews more effectively.

In studies, diversification of data sources, in other words, the inclusion of participants with different traits in the study, allows to reveal different perceptions and experiences on the researched phenomenon or case (Yıldırım \& Şimşek, 2005). In order to achieve diversity, the study was conducted in both primary and middle schools and the views of the administrators and teachers were obtained considering the gender, fields and type of duty differences.

\subsubsection{Administrator Interview Questions}

In its most general definition, procrastination is abstinence to start and complete tasks or make decisions that should be completed within a given period of time despite presence of adequate time and resources (information, money, hardware, goods, etc.) and the psychological discomfort (e.g., feeling uneasy, stress, anxiety) experienced by the individual as a result. Considering the definition given above, how would you assess your attitudes and behavior on the topic?

- How do you evaluate your role and responsibilities and workload within the context of procrastination of the duties at school? 


\subsubsection{Teacher Interview Questions}

In its most general definition, procrastination is abstinence to start and complete tasks or make decisions that should be completed within a given period of time despite presence of adequate time and resources (information, money, hardware, goods, etc.) and the psychological discomfort (e.g., feeling uneasy, stress, anxiety) experienced by the individual as a result. Considering the definition given above, how would you assess your administrators' attitudes and behavior on the topic?

- How do you evaluate the role and responsibilities and workload of your administrators within the context of procrastination of the duties at school?

The data were analyzed based on the teacher and administrator responses.

\subsection{Data Analysis}

In the data analysis process in the study, the data collected im interviews were transcribed based on the voice recordings and the concepts were combined and analyzed with content analysis. The main objective of content analysis is to determine the concepts and correlations that could explain the collected data (Yıldırım \& Şimşek, 2005). In the analysis, 12 interviewed school administrators were coded as A1...A12 and 18 teachers were coded as T1...T18 and their views were presented as quotations.

\section{Results}

In the context of the qualitative findings obtained with the interviews conducted with school administrators in the study, all school administrators $(f=12)$ stated that the work related to students, staff and education was not usually postponed at the school, however delays were experienced. Certain administrators mentioned communication especially sent by higher authorities and stated that certain delays were experienced in responding and announcing these communications to the staff. Certain administrative views on the topic were as follows:

A3. “...At our school, all tasks are completed on time. Because, if you postpone everything, you would not be able to manage anything after a while. We do not postpone today's tasks to tomorrow..."

A4. "...At our school, we usually to not postpone the tasks. We do the requested jobs as much as we can. Sometimes, when we have tasks that we need to complete urgently, we stay overtime at work... As the school administration, we never told a parent or teacher to come again tomorrow... If we receive an urgent communication with a deadline from the National Education Directorate, we immediately respond and send it..."

A6. "... When the work stops at the school, I could not rest due to my nature, I would want the tasks to be in order right away, this is my character. When you have too much stuff to take care of, you would be unable to work it out. If I cannot do it on time, then the workload increases, and I would be very tired..."

A3. “...We respond to the daily communication. But, if we are allowed to do it over a period of time, we can do it at the last minute..."

A7. "...Sometimes, it can be the last day to respond to urgent and daily communication from National Education. We need to collect information and research before sending a response. But, when we receive the communication, sometimes the it could be after the deadline or it could be the deadline that day, and we communicate it to the relevant teacher immediately, but the teacher thinks that we were the reason of the delay..."

However, the findings obtained in the interviews conducted with the teachers demonstrated that teachers did not agree with the administrators on procrastination. Most teachers interviewed in the study $(\mathrm{f}=13)$ stated that administrators delayed several tasks in the school. The views of certain teachers are presented below.

T8. "...Our administrators fulfill the tasks that are urgently required by the Directorate of National Education immediately, but they delay the work related to the school, the teachers and the students for a long time. Let me tell you about a recent incident. We had to use overhead devices for rehearsals for the Teachers' Day program. Even though I asked the administrators three days in advance, and provided the overhead device at the last minute. We had problems during the ceremony because we were not able to rehearse..."

T3. “...Almost every day, we experience procrastination problems at school. Although the letter of appointment did not arrive and I did not sign it, I became the object of an investigation. The investigation revealed that the letter was still at the office of the principal and I never signed it. There are serious 
about the announcement of the communications problems in our school. We just sign overdue and out of term letters after the deadline. In such cases, the school goes into a rush to meet the deadlines..."

T4. “...The seminar period prior to the academic year allows the duties to be completed easily at school. However, the administrators wait for the first day of school to complete the syllabus and school-related. On the first day, we go to school. There is neither a syllabus nor class schedule. When this is the case, the administrators panic. The duties of the administrators are handled by the teachers. This also affects the students. The classes of the students are unknown, leading to several uncertainties. Since the course schedule is not clear, the teacher cannot attend the classes, the classes become idle. During the first week of the academic year, we experience confusion, uncertainty and fuss due to the procrastination behavior of the administrators and this attitude leads to further delays."

T1. “...The urgent communications that arrive are immediately responded, but they always wait on the non-urgent communications without a deadline and this becomes a habit. When there is a decision that needs to be taken at the beginning of the academic year, they postpone the related meeting every day. And when it is the mid-academic year, there is still no decision. They panic, but then, it is too late."

T2. “... When there is a job to be done, administrators say that we can wait, there is still time and thus we can assess in thoroughly. However, nothing is done until the last day, and they cause a pressure on teachers to complete the task on the last day."

One of the important findings in terms of qualitative dimension is that, contrary to the teachers, some administrators state that postponement of work in the school is not caused by them, sometimes by the Directorate of National Education, sometimes by teachers and sometimes by financial and bureaucratic obstacles. Some of the managers' opinions on this issue are stated below.

A7: If some work is postponed at school, there is another reason. Although our school opened this year, our courses were not ready. Because there were changes in the regulation of secondary education institutions, in the 9th grade there was no geometry lesson, geometry lessons were put at the last moment, so the course schedule was delayed, the seizure schedule was delayed but these were not caused by us, the National Education informed us last minute. When the National Education sends us, it is already out of date. The teacher is not aware of the changes, so they think that we postpone our work teacher..."

A3: “...The postponement of some jobs may not originate from us, but from the Directorate of National Education. Sometimes school teachers are coming to school to be announced. But when it comes to school, it can already be past the day or the last day..."

A10: There is also a teacher dimension to postpone our work. For example, at the end of the semester, we usually wait for the final days for student grades to be enrolled in e-school. But it's because of teachers. Since teachers' notes are not in the system, we are delaying our work

The study findings demonstrated that administrators and teachers had different opinions on procrastination. Administrators mostly stated that they did not delay school work except for some unexpected delays. In contrast, teachers stated that administrators delayed certain duties and procedures related to students, teachers and the school. Previous study findings demonstrated that individuals' self-perceptions are generally more positive (Sayıner, Savaşan, Sözen, \& Köknel, 2007). Our self-consciousness includes our thoughts and perceptions about ourselves. Self-consciousness reflects to how we perceive ourselves, but self-consciousness may not always reflect reality. Or, we could perceive ourselves as successful even when we are unsuccessful (Cüceloglu, 2002). Or we may have a tendency to see ourselves as successful. Thus, considering that the individual has a tendency to perceive herself or himself more positively, it could be argued that the administrators exhibit partial procrastination behavior in practice. It would not be wrong to argue that administrators who consider themselves in an objective manner are closer to success.

Findings obtained in the interviews conducted with administrators on workload perceptions demonstrated that only two administrators were uneasy about the volume of their roles and responsibilities.

A6. “...Procurement of cleaning materials used in school bathrooms, renovation of broken windows and doors, repair of damaged faucets, maintenance and repair of the school equipment and desks, personnel documents and records of teachers, student registration and attendance records, cleaning of the school, meeting the demands of the parents... We do almost every job in the school from cleaning the bathrooms to the instruction of the courses. At the end, we are human, too; sometimes we feel depressed. Since we cannot do it all, we have to delay certain tasks."

A2. “...Sometimes, due to our high workload our hands are tied. Both student affairs, our course payments and salaries, as well as the parents. All of this, we cannot do it all. Even when we work 
organized, the work is intense and certain tasks are delayed. But when the work load is lighter, work is done. So, the high workload is not constant..."

The remaining ten administrators stated that the school workload was not at a level that could cause problems, and that they could balance their workload by distributing the roles and responsibilities among the administrators. The views of certain administrators are as follows.

A12. “... A good administrator would delegate the work to deputies. All deputies know their job description. When a school principal attempts to do everything or when the job descriptions of the deputies are not clear, the work is delayed."

A2. “...The school principal must share his/her authority and responsibility with the deputies... The job description and responsibilities of a principal are clearly described in Primary Education Institution Regulations. For example, I delegate my responsibilities set out in the regulations to my deputies, thus reducing my workload. This division of labor makes it easy for my deputy directors as well. Otherwise, they would say I would not do it, the other deputy should do it."

A6. "...If an administrator says that her or his workload is too heavy, it means that she/he is not doing her/his job properly... The administrative team should work in collaboration to complete all tasks on time. The administrator should help the deputies and they should help the principal."

A11. “...Due to the high workload, I do not think that some of the tasks are completed at the last minute. I think our principal and we work together in order not to postpone the tasks, we support each other. But there are also administrators who make a habit of procrastination."

A4. “...The job description of everyone at school is clear, but I would like to see everything as administrator. If the work is delayed, either the principal and the deputies have no clear job descriptions or they unaware of the school operations."

However, the findings obtained in the interviews conducted with the teachers demonstrated that teachers did not agree with the administrators on workload and delegation of responsibilities.

Only one teacher stated that there was a division of labor among the school administrators, while others $(f=9)$ reported negative views on this topic. The teachers with negative views stated that there was no distribution of labor among school administrators, or there were disagreements about the areas of responsibility among the administrators. Teachers also stated that administrators refused the requests of teachers on the pretext that they had excess workload and procrastinated. Certain views of the teachers are presented below.

T2. “...Since the job description of each deputy is clear, the system works smoothly. No one has to tell others what to do..."

T13. “...The administrators always disrupt and delay the tasks with the pretext that they have a high workload. But they immediately handle unnecessary tasks. I think that they could complete all tasks by listing them in the order of importance, but they continuously complain about their workload..."

T3. “...Sometimes the teachers have to procure something for use in the classroom. The administrators say they would provide the article; however, they do not keep their promise. Then, they say do it yourself, there are ... teachers ... students at school, which of these should we deal with..."

T7. “...Sometimes the administrators have disagreements among themselves. This has a negative impact on school tasks. If something is going to be done, everyone expect something from the others, but no one makes an attempt. Since the job descriptions of the deputies are undetermined, everyone expects someone else to do the job. This causes delays and procrastination..."

T4. “...Sometimes although the duties and responsibilities are predetermined, but deputies expect each other to do the job. This leads to jobs to be completed on the last day and stress..."

T6. “... Since our principal is a perfectionist, he even tries to do the jobs of the deputies, does not delegate tasks and procrastinates since he tries to do everything himself..."

The teachers stated that the administrators procrastinated with the pretext that they had a high workload.

\section{Discussion and Conclusion}

The interviews conducted with teachers and administrators and demonstrated that administrators did not delay urgent tasks with a deadline sent by higher authorities but delayed the tasks that were earmarked as non-urgent. Based on this finding, to avoid procrastination, administrators are expected to have self-control, internalize their duties and possess a high job satisfaction and organizational commitment. Thus, it should be ensured that abstinence from procrastination 
should not be only prevented by external sanctions but the administrators should internalize it and their active time management and self-control skills should be developed.

In the interviews, administrators and teachers stated that certain tasks are delayed at the school due to the fact that administrators did not clearly delegate their authority to other administrators. Based on these findings that supported one another, it can be argued that the roles, duties and authority delegations among the administrators and deputy administrators should be clarified and be more systematic.

Interviewed teachers argued that procrastination may be related to the failure of the administrators to delegate their powers and responsibilities with the deputies or due to the fact that the distribution of labor among the administrators was not clear. Based on this finding, it could be advised to conduct future studies to determine the correlation between administrators' leadership styles, delegation of authority and procrastination tendencies.

\section{References}

Başaran, İ. E. (2000). Educational Administration: Qualified School (3rd Ed.). Ankara, Feryal Press.

Bolat, O. İ. (2011). Workload, Business Control and Burnout Relationship. Atatürk University Journal of Economics and Administrative Sciences, 25(2), 87-99.

Burka, J. B., \& Yuen, L. M. (2008). Procrastination: Why you do it, what to do about it (Revised Edition). US: DaCapo Press.

Çakıcı, D. Ç. (2003). Investigation of Procrastination Behavior and General Procrastination in Scholarship in High School and University Students. Unpublished Master's Thesis. Ankara University, Institute of Educational Sciences, Ankara.

Chu, A. H. C., \& Choi, J. N. (2005). Rethinking procrastination: Positive effects of "active" procrastination behavior on attitudes and performance. Journal of Social Psychology, 14, 245-264. https://doi.org/10.3200/SOCP.145.3.245-264

Cüceloglu, D. (2002). Human and behavior (11th Ed.). İstanbul, Remzi Press.

Cunningham, C. J. L. (2007). Need for recovery and ineffective self-management. Unpublished Doctoral Dissertation, Bowling Green State University, http://rave.ohiolink.edu/etdc/view?acc_num=bgsu1179866357.

DiPaola, M. F., \& Walther-Thomas, C. (2003). Principals and special education: The critical role of school leaders. Center on Personnel Studies in Special Education, COPPSE Document No. IB-7.

Ellis A., \& Klause, W. J. (1977). Overcoming Procrastination: Or how to Think and Act Rationally in Spite of Life's Inevitable Hassles. Institute for Rational Living.

Erdem, H., Kılınç, E., \& Demirci, D. (2016). The Effect of Workload Surplus on Perceived Employability in Employees. Electronic Journal of Social Sciences, 15(58), 772-784.

Ferrari, J. R. (1994). Dysfunctional procrastination and its relationship with selfesteem,interpersonal dependency, and self-defeating behaviors. Personality and Individual Differences, 17, 673-679. https://doi.org/10.1016/0191-8869(94)90140-6

Ferrari, J. R., Johnson, J. L., \& McCown, W. G. (1995). Procrastination and task avoidance: Theory, research, and treatment. New York, NY, USA: Plenum Press. https://doi.org/10.1007/978-1-4899-0227-6

Galue, A. J. (1990). Perceived job ambiguity, predisposition to procrastinate workrelated information and experience: an investigation of procrastination behavior at work. Unpublished Doctoral Dissertation. The University of Tulane-Ottowa,Ontario.

Groff, F. (2001). Who will lead? The principal shortage. State Legislatures. 27(9), 16-19.

Güçlü, N. (2001). Time management. Educational Administration in Theory and Practice, 7(25), 87-106.

Gülebağlan, C. (2003). A study on the comparison of the last major postponement tendencies of teachers in terms of their professional competence perceptions, professional experiences and branches. Unpublished Master's Thesis, Ankara University, Institute of Educational Sciences-Ankara.

Hallinger, P. (1992). The evolving role of American principals: from managerial to instructional to transformational leaders. Journal of Educational Administration, 30(3), 35-48. https://doi.org/10.1108/09578239210014306

Harriott, J., \& Ferrari, J. R. (1996). Prevalence of procrastination among samples of adults. Psychological Reports, 78, 611-616. https://doi.org/10.2466/pr0.1996.78.2.611

Johnson, E. M., Green, K. E., \& Kluever, R. C. (2000). Psychometric characteristics of the revised procrastination 
inventory. Research in Higher Education, 41(2), 269-279. https://doi.org/10.1023/A:1007051423054

Milgram, N. A. (1991). Procrastination. In R. Dulbecco (Ed.), Encyclopedia of human biology (Vol. 6, pp. 149-155). New York: Academic Press.

Milgram, N. A., \& Tenne, R. (2000). Personality correlates of decisional and task avoidant procrastination. European Journal of Personality, 14, 141-156. https://doi.org/10.1002/(SICI)1099-0984(200003/04)14:2<141::AID-PER369>3.0.CO;2-V

Portin, B. S. (2000). The Changing Urban Principalship. Education and Urban Society, 32(4), 492-505. https://doi.org/10.1177/0013124500324005

Sayıner, B., Savaşan, E., Sözen, D., \& Köknel, Ö. (2007). Examination of the self-perception of the higher education youth according to various variables: Istanbul Commerce University Case. Istanbul Commerce University Journal of Social Sciences, 6(11), 253-265.

Senécal, C., Koestner, R., \& Vallerand, R. J. (1995). Self-regulation and academic procrastination. Journal of Social Psychology, 135(1), 607-619. https://doi.org/10.1080/00224545.1995.9712234

Solomon, L. J., \& Rothblum, E. D. (1984). Academic procrastination: Frequency and cognitive-behavioral correlates. Journal of Counseling Psychology, 31, 503-509. https://doi.org/10.1037/0022-0167.31.4.503

Subotnik, R., Steiner, C., \& Chakraborty, B. (1999). Procrastination revisited: The constructive use of delayed response. Creativity Research Journal, 12(2), 151-160. https://doi.org/10.1207/s15326934crj1202_7

Taymaz, H. (2000). School Management. (5th Ed.).Ankara: Pegem A Publishing.

Tuckman, B. W. (1990,). Measuring procrastination attitudinally and behaviorally. Paper presented at the annual meeting of the American Educational Rsearch Association, Boston, MA. (Eric Document Reproduction Service No: ED 319 792).

Tuckman, B. W. (1991). The development and concurrent validity of the procrastination scale. Educational and Psychological Measurement, 51, 473-480. https://doi.org/10.1177/0013164491512022

Uysal, H. T., Akbulut, H., \& Ertan, S. (2015). The Effect of Extreme Workload from Performance Perspective on Negative Study in Working Psychology: A Research on Accounting Professionals. International Journal of Social Research, 8(38), 980-991. https://doi.org/10.17719/jisr.20153813703

Uzun-Özer, B. (2005). Academic procrastination: Prevalence, self-reported reasons, gender difference and it's relation with academic achievement. Unpublished Master Thesis. Middle East Technical University-Ankara.

Vatansever, Ç. (2014). A New Dimension in Risk Assessment: Psychosocial Hazards and Risks. Journal of Work and Society, 40(1).

Vestervelt, C. M. (2000). An examination of the cobtent and construct validity of four measures of procrastination. Unpublished Master Dissertation. The University of Carleton-Ottowa, Ontario

Watson, D. C. (2001). Procrastination and the five-factor model: A facet level analysis. Personality and Individual Differences, 30, 149-158. https://doi.org/10.1016/S0191-8869(00)00019-2

Whitaker, K. S. (1998). The changing landscape of the principalship: view from the inside, Planning and Changing, 29(3), 130-50.

Whitaker, K. S. (1999). Principal role changes and implications for principal candidates, International Journal of Educational Reform, 8(4), 352-362.

Whitaker, K. S. (2002). Principal role changes and influence on principal recruitment and selection. Journal of Educational Administration, 41(1), 37-54. https://doi.org/10.1108/09578230310457420

Williams, R. C., \& Portin, B. (1997, April). The changing role of the principal in Washington state, paper presented at the Annual Meeting of the American Educational Research Association, Chicago, IL.

Yıldırım, A., \& Şimşek, H. (2005). Qualitative research methods in social sciences (5th Ed.). Ankara: Seçkin Publishing.

\section{Copyrights}

Copyright for this article is retained by the author(s), with first publication rights granted to the journal.

This is an open-access article distributed under the terms and conditions of the Creative Commons Attribution license which permits unrestricted use, distribution, and reproduction in any medium, provided the original work is properly cited. 